\title{
Synthesis, Spectral Characterization and Antimicrobial Activity of Some Transition Metal Complexes with New Schiff Base Ligand (BDABI)
}

\author{
FAWZI YAHYA WADDAI ${ }^{1}$, EBTIHAL KADHUM KAREEM ${ }^{2}$ and SAHAR AQEEL HUSSAIN ${ }^{3}$ \\ ${ }^{1}$ Chemistry Department, Faculty of Science, Kufa University, Al-Najaf -31001-Iraq. \\ ${ }^{2}$ Chemistry Department, Faculty of Education for Women, Kufa University, Al-Najaf -31001-Iraq. \\ ${ }^{3}$ Pharmaceutical Chemistry Department -Faculty of Pharmacy, Kufa University,Al-Najaf -31001-Iraq. \\ ${ }^{*}$ Corresponding author E-mail: Fawzi.almuwashi@uokufa.edu.iq
}

http://dx.doi.org/10.13005/ojc/340147

(Received: Octuber 05, 2017; Accepted: November 26, 2017)

\begin{abstract}
A new Schiff base derivative ligand (LI) have been produced by condensed isatin and 2,3-diaminobutane (2:1) molar ratio. The (LI) ligand has been separated and distinguished by ${ }^{1} \mathrm{H},{ }^{13} \mathrm{C}$-NMR, (CHN) elemental analysis, UV-visible, mass spectroscopy and Fourier Transform infrared (FTIR) methods. The metal ions, cobalt(II), nickel(II) and copper(II) complexes were synthesized with the ligand. The complexes were typified by, UV-Visible, FTIR, atomic absorption, molar conductance, magnetic susceptibility and elemental analysis $(\mathrm{CHN})$ techniques. Octahedral geometry are suggested for the metal complexes based on the results of physico-chemical and spectral techniques. The TLC for (LI) ligand and complexes demonstrated single spot for each, signifying their compounds purity. All these compounds were determined aligned with two classes of human pathogenic; bacteria Gram positive and Gram negative.
\end{abstract}

Keywords: Synthesis, Characterization, Schiff base, Complexes, Antimicrobial activity.

\section{INTRODUCTION}

Isatin represents synthetically $1 \mathrm{H}$-indole2,3-dione and it is a flexible lead molecule for latent bioactive agents ${ }^{1}$. The chemical versatility of isatin motivated the widespread use of this compound in biological synthesis ${ }^{2}$. Isatin nucleus having carbonyl group both the lactam and keto position 2 and 3 respectively can either go through addition reaction at the $\mathrm{C}-\mathrm{O}$ bond or form concentration products with water release. Throughout the $\mathrm{NH}$ group, isatin compound series are able to access $\mathrm{N}$-acetylation and $\mathrm{N}$-alkylation ${ }^{3}$. Isatin is the mainly proficient class of fragrant heterocyclic organic complexes that has a lot of remarkable active outlines and able-bodied in human subjects ${ }^{4}$. The isatin ring is a major structural pattern existing in numerous pharmaceutically active complexes. This

This is an $\mathbf{O}$ Open Access article licensed under a Creative Commons Attribution-NonCommercial-ShareAlike 4.0 International License (https://creativecommons.org/licenses/by-nc-sa/4.0/ ), which permits unrestricted NonCommercial use, distribution and reproduction in any medium, provided the original work is properly cited. 
is essentially because of the straightforward synthesis and the pharmacological activity significance. Consequently, the discriminating functionalization and isatins synthesis are the central point in the reported papers over the years ${ }^{5}$. The derivatives of isatin have been particularly important recently. They have appeared to be antibacterial and antifunga ${ }^{6}$ agents of a huge attention owing to their wide-ranging spectrum of in vivo and in vitro therapeutic activities ${ }^{7}$. The bases of Schiff are typified by the $-\mathrm{N}=\mathrm{CH}$ - (azomethine group) that are typically created from the prime amines condensation and effective carbonyl group ${ }^{8,9}$. Schiff bases are forming some imperative kinds of biological compounds in view of the fact that they have different donor atoms and are capable of changing reaction based on the initial reagent. This category of compounds includes a broad diversity of organic features ${ }^{10}$. Schiff bases can be used in industrial chemistry and inorganic chemistry field ${ }^{11}$. Also, they are adopted as substrates in the preparing of some organically active complexes by means of ring cycloaddition, closure, and substitution reactions ${ }^{12}$. Furthermore, Schiff bases originated from diverse heterocycles had been recorded in the literature to have cytotoxic ${ }^{13}$, antimicrobial ${ }^{14}$, anticancer ${ }^{15}$, and antifungal activities ${ }^{16}$. As a result of huge flexibility and varied structural characteristics, diverse Schiff bases have synthesized and their complexation performance was investigated ${ }^{9}$. The compounds of Schiff base can be employed as ligands in coordination chemistry, it usually bi, tri, tetra-dentate ligands able to form extremely steady complexes with transition metals. Tetradentate ligands having imine clusters are utilized as modulators of constitutional and electronic characteristics of transitional metal centers ${ }^{17,18}$. Schiff bases are typified by their capacity to fully organize a metal ion, structuring chelate rings and the ligand. They locate their appliances as the investigative reagent for determination of metals ${ }^{17}$. Transitional metal complexes reliant on the Schiff base ligands have studied for a lot of years. Reported papers on Schiff base complexes of metals attract inorganic chemists up to date as a consequence of their widespread fields and applications, synthesis simplicity and use as organic models $^{19}$.
In this study, a straightforward synthetic technique to synthesize the Schiff base ligand from isatin and 2,3-diamino butane and its metal chelate complexes has been presented. The formation of these compounds has been explained through spectroscopic techniques.

\section{EXPERIMENTAL}

\section{Instruments, materials and methods}

The entire compounds had been bought from BDH and Fluka. FTIR spectra had been measured in $\mathrm{KBr}$ on Shimadzu- spectrophotometer within (4000-400) $\mathrm{cm}^{-1}$. Spectrum in ethanol had been measured using the UV-visible spectrophotometer of Shimadzu type within (200-1100) nm range with $1 \mathrm{~cm}$ quartz cell length. Melting points had been calculated by SMP30 electro thermal Stuart equipment. The measurements of complexes electrical conductivity had been measured at $\left(25^{\circ} \mathrm{C}\right)$ for $10-3 \mathrm{~mol}$. L-1 solution in dimethyl sulfoxide (DMSO) samples by means of WTW inolabcond 720 digital conductivity meter. Mass spectra in agilent mass spectrometer 5975 quadropoleanalyser.

${ }^{1} \mathrm{H}$ NMR and ${ }^{13} \mathrm{C}$ NMR spectra had been calculated on a DRX (500-MHz) spectrometer in DMSO and Bruner DRX (500-MHz). The shifts of compounds are in ppm in relation to interior Me4Si. Fundamental microanalyses of the ligand and their complexes had been achieved by using Euro Vectro-3000A. The materials and solutions which used in the biological study Sterilized by using Autoclave, Gallen Kamp. The cultivated bacteria dishes incubated by using Memmert Incubator, 854 Schwach.

The content of complex metal had been evaluated using atomic absorption method via Analytic Jena(A.A350) atomic absorption Spectrophotometer. Magnetic susceptibility magnitudes had been found at room temperature by the Gouy technique and Johnson Mattey Catalytic system. Thin Layer Chromatography (TLC) had been achieved on aluminum plates covered with silica gel (Fluka), and detected by iodine. 


\section{Synthesis of ligand (LI)}

An isatin solution $(2.94 \mathrm{~g}, 0.02 \mathrm{~mol})$ in absolute ethanol $(30 \mathrm{~mL})$ had been inserted to a refluxing solution of 2,3-diamino butane $(0.88$ $\mathrm{g}, 0.01 \mathrm{~mol})$ in the similar solvent $(15 \mathrm{~mL})$ in $(100$ $\mathrm{mL}$ ) round bottomed flask. A small number of glacial acetic acid drops had been inserted. The reactional combination had been excited under reflux at $\left(80^{\circ} \mathrm{C}\right)$ for $6 \mathrm{~h}$ with nonstop stirring. The solution color had been altered from orange to light brown and subsequently the brown precipitate pattern. The reaction development had been observed by TLC. After completion of the reaction and standing for approximately $24 \mathrm{~h}$ at room temperature. The resultant solid had been composed by filtration, washed with absolute ethanol and dried in open air and purified by recrystalization from hot absolute ethanol and dried at ambient temperature. Scheme 1 shows the preparation of the ligand ; yield: $79.2 \%$, m.p.: $174-175^{\circ} \mathrm{C}$.

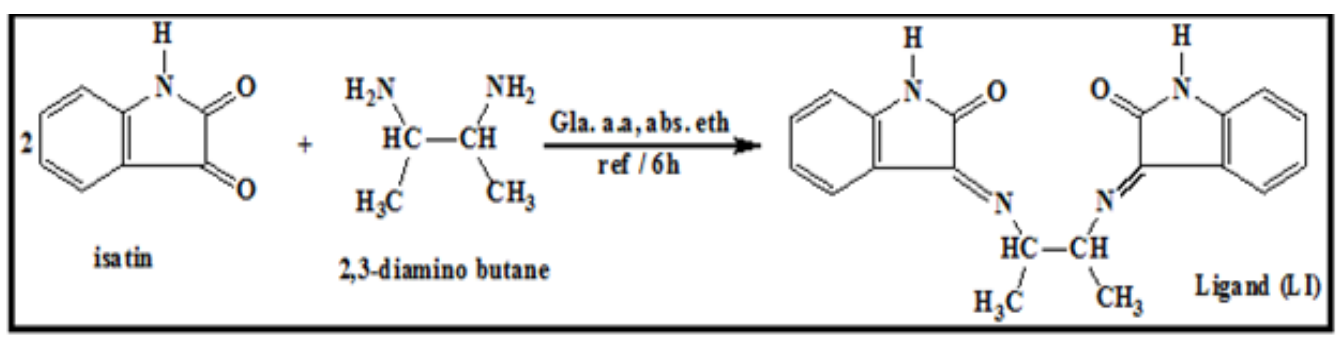

Scheme1. Preparation of the Schiff base ligand (LI)

\section{(Co, $\mathrm{Ni}$ and $\mathrm{Cu}$ ) Complexes Synthesis}

Toward a solution of the (LI) $(0.346 \mathrm{~g}, 2$ $\mathrm{mmol})$ in 20 mlabsolute ethanol, $(1 \mathrm{mmol}$ of metal chloride) in $20 \mathrm{ml}$ ethanol $0.238 \mathrm{~g} \mathrm{CoCl}_{2} \cdot 6 \mathrm{H}_{2} \mathrm{O}$, $0.237 \mathrm{~g} \mathrm{NiCl}_{2} \cdot 6 \mathrm{H}_{2} \mathrm{O}, 0.170 \mathrm{~g} \mathrm{CuCl}_{2} \cdot 2 \mathrm{H}_{2} \mathrm{O}$, had been put in. The solutions had been refluxed for sixty minutes and left to fade away gradually to overthrow the complexes. The complexes were washed from mixture of ethanol + distilled water (1:1), and recrystallized from hot absolute ethanol. The secluded complexes are highlighted solids by colors, steady in air and unsolvable in water but totally soluble in most organic solvents such as DMSO and DMF. A number of chemical and physical features for every synthesized ligand (LI) and its complexes have been depicted in Table. 1.

\section{Antimicrobial activity Study}

Antibacterial behavior of the Schiff base and its metal complexes had been monitored by Kirby-Bauer disk diffusion method ${ }^{20}$. This study used two strains of pathogenic bacteria first, a Staphylococcus aureus (Gram Positive) and the other strain, Escherichia coli. (Gram Negative). The chemical solutions used in the biological study are prepared by using dimethyl sulfoxide (DMSO) as solvent, where attended a single concentration (C) $1 \times 10-3 \mathrm{M}$. The dishes are incubated at a temperature of $37^{\circ} \mathrm{C}$ for 24 hours. Taking the inhibition zones, Inhibition diameter $\mathrm{mm}$ was formed after $24 \mathrm{~h}$ as a criterion for the intensity of the effect synthetic chemical compounds on the growth of cultivated particular bacteria strains.

\section{RESULTS AND DISCUSSION}

\section{General}

The Schiff base ligand (LI) is yellowishorange crystal, which is partially soluble in water and soluble in universal biological solvents. The reaction of this ligand with the metal ions gives different color crystals. All complexes are reasonably air-stable, insoluble in water, but soluble in most organic solvents.

\section{Physical characteristics and Elemental Investigation}

The physical characteristics and outcomes taken from C.H.N. investigation and metal substances of the arranged compounds are explained in Table. 1. The investigative data had been acceptable with planned magnitudes. The molecular procedure of the ligand and its metal compounds had been proposed in relation to these data jointly with those acquired from spectral in addition to magnetic susceptibility of metal compounds. Every (1:1) metal to ligand solid complexes have been separated. 


\section{IR spectra}

The infrared spectra give worthy details concerning the features of the functional groups in the ligand and some of which added to the metal ion. ${ }^{17,21}$ The IR spectrum of the free ligand (LI), showed the absorption band nonexistence at 3266 $\mathrm{cm}^{-1}$ at the level of stretched vibration of $v(\mathrm{~N}-\mathrm{H})$ of the isatin moiety ${ }^{22,23,24}$, the location of this band stayed at almost the similar frequency in spectra of the metal complexes, signifying the uncoordinated group ${ }^{25,26}$. The band at $1739 \mathrm{~cm}^{-1}$ in the free ligand spectrum based on $v(C=O)$ lactam of isatin moiety ${ }^{17,27}$ shifted towards lower values, around $1694-11680 \mathrm{~cm}^{-1}$, in the complexes, signifying the coordinated lactam carbonyl oxygen atom of the isatin residue ${ }^{17,28}$. The band appearing at $1653 \mathrm{~cm}^{-1}$ in the free ligand, assignable to the $v(\mathrm{C}=\mathrm{N})$ vibration mode $^{27,29}$, is moved to minor wave numbers with a

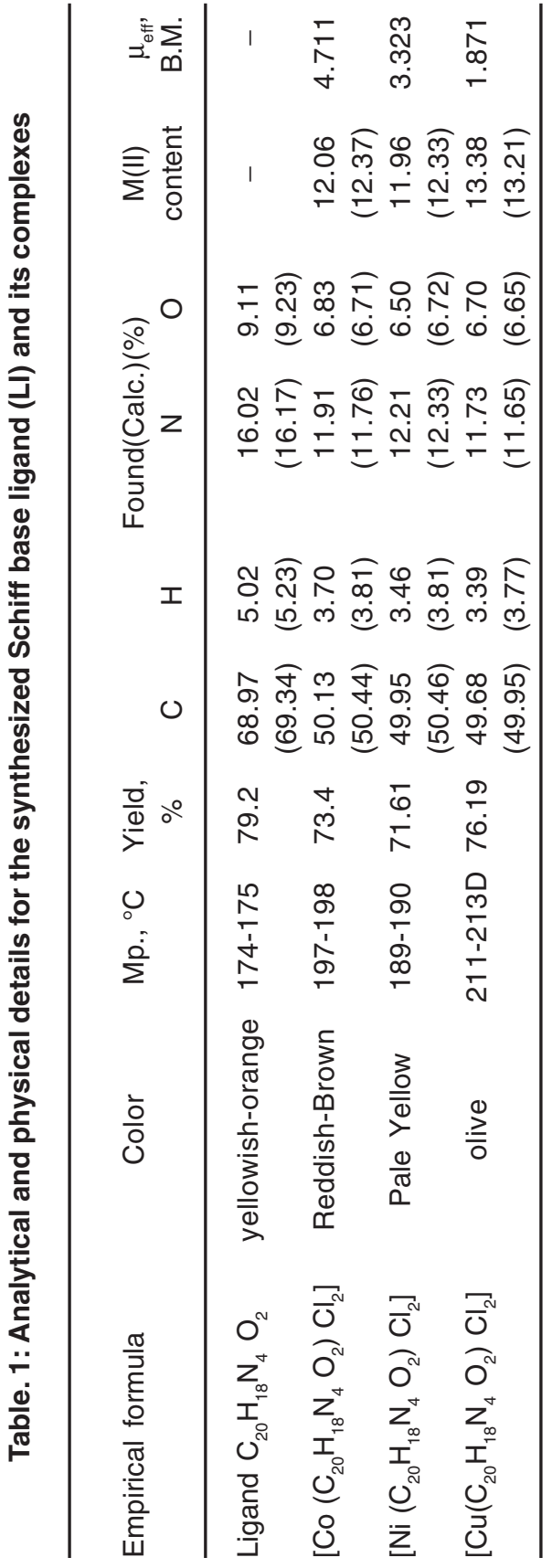

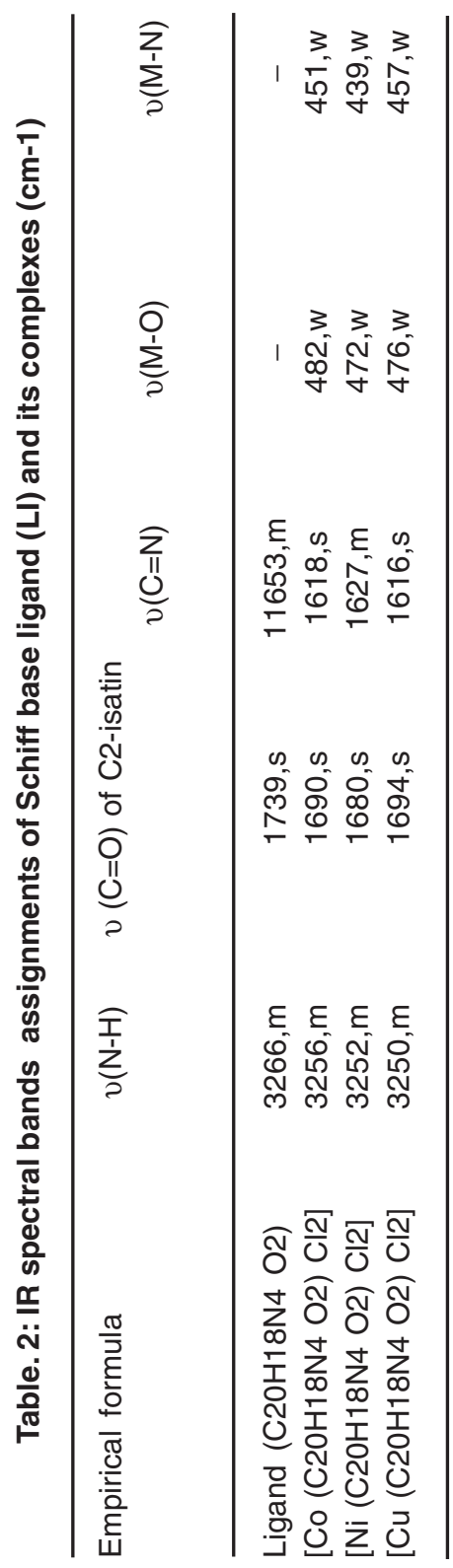


$\Delta v=(37-26) \mathrm{cm}^{-1}$ in the complexes spectra, this signifying the concern of azomethinic nitrogen atom in coordination ${ }^{21,28}$. The form of dual new bands in the region $482-472$ and $457-439 \mathrm{~cm}^{-1}$ in the spectra of the complexes is due to $v(\mathrm{M}-\mathrm{O})$ and $v(\mathrm{M}-\mathrm{N})$ stretching vibrations correspondingly $\mathrm{y}^{21,29}$. Besides, it proved the metal complexes structure. The characteristic IR data for all compounds are described in Table. 2.
The ${ }^{1} \mathrm{H}-\mathrm{NMR}$ spectrum of (LI) in DMSO-d6 in Fig. 1 showed a solitary peak come into view at $\delta(8.413)$ and a manifold peaks at $\delta(7.517-7.761)$ ppm that had been attributed to chemical shifts of $\mathrm{NH}$ and aromatic protons of isatin moiety ${ }^{24,27,30}$. The observed doublet signal at $\delta(1.369,1.397) \mathrm{ppm}$ and multiplet peak at $\delta(3.450-3.569)$ ppm were assigned to $\mathrm{N}-\mathrm{C}-\mathrm{H}^{27,30}$ and $\mathrm{C}-\mathrm{CH}_{3}{ }^{30}$ protons on the diaminobutane moiety in the ligand respectively.

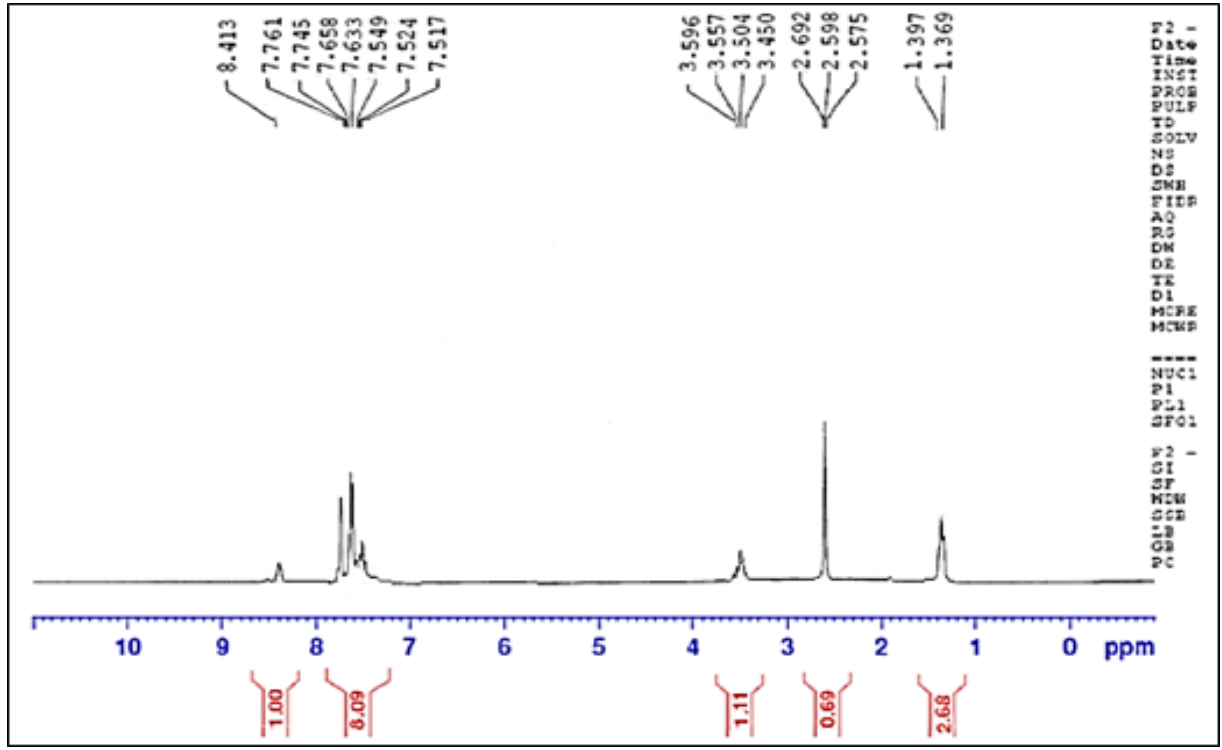

Fig. 1. ${ }^{1} \mathrm{H}-\mathrm{NMR}$ spectrum of the Schiff base ligand (LI)

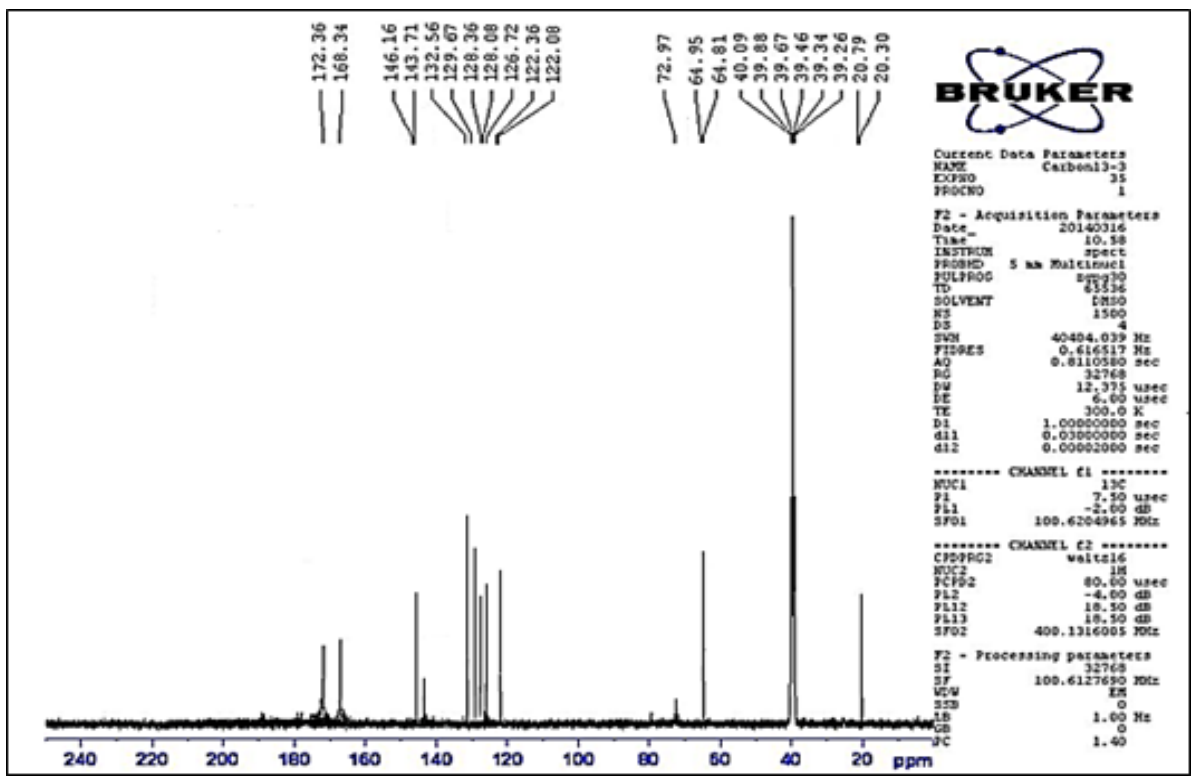

Fig. 2. ${ }^{13} \mathrm{C}$-NMR spectrum of the Schiff base ligand (니) 
The ${ }^{13} \mathrm{C}$-NMR spectrum Fig. 2 displayed a peak at $\delta(172)$ ppm which is due to lactam carbonyl group ${ }^{25}$, while the $\mathrm{N}=\mathrm{C}$ (azomethine group) carbon signal is showed at $\delta(168) \mathrm{ppm}^{23,24}$. The multiplet peaks at $\delta(122-146) \mathrm{ppm}$ are due to aromatic carbons of isatin moiety ${ }^{24}$. The signals at $\delta(64$ and 20) ppm are assigned to the middle and terminal

Table. 3: Shows the RF for the Schiff base ligand (LI) and its complexes

\begin{tabular}{lcr}
\hline Compound & $\begin{array}{c}\text { Molecular weight } \\
(\mathrm{g} / \mathrm{mol})\end{array}$ & $\mathrm{Rf}$ \\
\hline (LI) $\mathrm{C}_{20} \mathrm{H}_{18} \mathrm{~N}_{4} \mathrm{O}_{2}$ & 346.38 & 0.49 \\
{$\left[\mathrm{Co}\left(\mathrm{C}_{20} \mathrm{H}_{18} \mathrm{~N}_{4} \mathrm{O}_{2}\right) \mathrm{Cl}_{2}\right]$} & 476.21 & 0.38 \\
{$\left[\mathrm{Ni}\left(\mathrm{C}_{20} \mathrm{H}_{18} \mathrm{~N}_{4} \mathrm{O}_{2}\right) \mathrm{Cl}_{2}\right]$} & 475.97 & 0.35 \\
{$\left[\mathrm{Cu}\left(\mathrm{C}_{20} \mathrm{H}_{18} \mathrm{~N}_{4} \mathrm{O}_{2}\right) \mathrm{Cl}_{2}\right]$} & 480.83 & 0.27 \\
\hline
\end{tabular}

C-C carbon atoms of diaminobutane moiety in the ligand ${ }^{23,30}$.

\section{Thin layer chromatography (TLC)}

The ligand (LI) solution and its compounds in ethanol as solvent have come into view as single spot. Each has confirmed that every one of these compounds are clear and have just single isomer. Table. 3 illustrates the Rf for complexes and the ligand.

\section{UV-VIS Spectral studies}

The electronically absorption bands plus the conductivity magnitudes have been presented in Table 4. The UV-Visible spectrum of $\mathrm{LI}$ in ethanol appeared two absorptions at (240 and 291) $\mathrm{nm}$ (41666 and 34364) $\mathrm{cm}^{-1}$, which is due to $\pi \rightarrow \pi^{*}$ transition and a broad low intensity band at (422) $\mathrm{nm}$ (23696) $\mathrm{cm}-1$, which had been related to $\Pi \rightarrow \Pi^{*}$ changeover ${ }^{23,27}$.

Table. 4: Electronic spectral bands $\left(\mathrm{cm}^{-1}\right)$ and conductivity of the complexes

\begin{tabular}{|c|c|c|c|c|c|c|c|}
\hline Complex & Band position, $\mathrm{cm}^{-1}$ & Assignments & $B_{\text {complex }}$ & $\beta$ & $\mathrm{Dq} / \mathrm{B}$ & $\begin{array}{c}10 D q\left(v_{1}\right) \\
\text { theoretical, } \\
\mathrm{cm}^{-1}\end{array}$ & $\underset{\Omega^{-1} \mathrm{~cm}^{2} \cdot \mathrm{mol}^{-1}}{\Lambda_{\mathrm{m}}}$ \\
\hline LI-Co(II) & $\begin{array}{c}19320.76 \mathrm{v} 3 \\
15923.56 \mathrm{v} 2 \\
13149.24 \text { (cal.) }\end{array}$ & $\begin{array}{l}{ }^{4} \mathrm{~T}_{1} \mathrm{~g} \rightarrow{ }^{4} \mathrm{~T}_{1} \mathrm{~g}_{(\mathrm{P})} \\
{ }^{4} \mathrm{~T}_{1} \mathrm{~g} \rightarrow{ }^{4} \mathrm{~A}_{2} \mathrm{~g}_{(\mathrm{F})} \\
{ }^{4} \mathrm{~T}_{1} \mathrm{~g} \rightarrow{ }^{4} \mathrm{~T}_{2} \mathrm{~g}_{(\mathrm{p})}\end{array}$ & 692.32 & 0.71 & $(1.89)$ & 13149.24 & 9.03 \\
\hline LI-Ni(II) & $\begin{array}{c}21413.27 \mathrm{v} 3 \\
14925.37 \mathrm{v} 2 \\
8291.87 \text { (cal.) }\end{array}$ & $\begin{array}{l}{ }^{3} \mathrm{~A}_{2} \mathrm{~g} \rightarrow{ }^{3} \mathrm{~T}_{1} \mathrm{~g}_{(\mathrm{P})} \\
{ }^{3} \mathrm{~A}_{2} \mathrm{~g} \rightarrow{ }^{3} \mathrm{~T}_{1} \mathrm{~g}_{(\mathrm{F})} \\
{ }^{3} \mathrm{~A}_{2} \mathrm{~g} \rightarrow 3 \mathrm{~T}_{2} \mathrm{~g}_{(\mathrm{F})}\end{array}$ & 829.87 & 0.7 & $(1.08)$ & 8291.87 & 13.53 \\
\hline LI-Cu(II) & 13831.2 & ${ }^{2} \mathrm{Eg} \rightarrow{ }^{2} \mathrm{~T}_{2} \mathrm{~g}$ & - & - & - & - & 11.51 \\
\hline
\end{tabular}

The spectral properties of the metal complexes showed bathochromic shifts of ligand band. The bands assigned to intraligand $\pi \rightarrow \pi^{\star}$ for the $\mathrm{Co}(\mathrm{II}), \mathrm{Ni}(\mathrm{II})$, and $\mathrm{Cu}(\mathrm{II})$ complexes were observed at $(39525,33112),(38910,32362)$ and (38167, 31446) $\mathrm{cm}^{-1}$ correspondingly.

The transition metal complexes spectrum illustrated extra small intensity bands in the visible regions based on ligand field $d$ - $d$ transitions ${ }^{21}$. Spectrum of Co-complex in ethanol solution revealed dual bands appearing at (628) $\mathrm{nm}$ (15923.56) $\mathrm{cm}^{-1}$ and (517.57) $\mathrm{nm}(19320.76) \mathrm{cm}^{-1}$, which were related to the $4 \mathrm{~T} 1_{\mathrm{g}} \rightarrow 4 \mathrm{~A} 2_{\mathrm{g}} \quad\left(v_{2}\right)$ and $4 \mathrm{~T} 1_{\mathrm{g}} \rightarrow 4 \mathrm{~T} 1_{\mathrm{g}}(\mathrm{P})\left(v_{3}\right)$ transitions correspondingly of octahedral structure ${ }^{31}$. Based on $3 / 2$ ratio of (1.21), the value of $D q / B(1.89)$ had gotten. The magnitude of $B^{\prime}(692.32)$ in addition to the position of $v 1(10 \mathrm{Dq})$ of $13149.24 \mathrm{~cm}^{-1}$ had been evaluated via TanabaSugano diagram for $d 7$ configuration of the octahedral formation ${ }^{31}$. The (0.71) magnitude points to several covalent character. The measured conductivity shows that the Co-complex is not ionic. Spectrum of $\mathrm{Ni}$ (II) complex demonstrated dual bands in the visible region at (467) $\mathrm{nm}(21413.27) \mathrm{cm}^{-1}$, and $(670) \mathrm{nm}(14925.37) \mathrm{cm}^{-1}$ that are due to $3 \mathrm{~A} 2 \mathrm{~g} \rightarrow 3 \mathrm{~T} 1_{\mathrm{g}}(\mathrm{P}) \quad$ (v3), $\quad 3 \mathrm{~A} 2_{\mathrm{g}} \rightarrow 3 \mathrm{~T} 1_{\mathrm{g}}(\mathrm{F}) \quad$ (v2) correspondingly. The $3 / 2$ ratio of $(1.43)$ was used in Tanaba-Sugano diagram for d8 octahedral complexes $^{31,32} \mathrm{~B}_{\text {complex }}$ (764) $\beta$ and (0.7), Dq/B (1.08), $10 \mathrm{Dq}(01)$ (8291.87) $\mathrm{cm}^{-1}$ had been in theory determined. The conductivity explained that the $\mathrm{Ni}(\mathrm{II})$-complex had been not electrolyte. The 
spectrum of $\mathrm{Cu}(\mathrm{II})$ complex illustrated broadband at (723) nm (13831.2) $\mathrm{cm}^{-1}$ assigned to ${ }^{2} \mathrm{E}_{\mathrm{g}} \rightarrow{ }^{2} \mathrm{~T}_{2 \mathrm{~g}}$ transition that denote Jahn-Teller distorting of octahedral geometry. ${ }^{32,33}$ The measured conductivity of the complex explained that the complex has not been ionic.

\section{Mass spectrum for the Schiff base ligand (LI)}

The mass spectrum data for ligand(LI) Fig. 3 depicted a peak of molecular ion at $(\mathrm{m} / \mathrm{z}=346.7)^{34}$. The molecular ion peak corresponds to $\left(\mathrm{C}_{20} \mathrm{H}_{18} \mathrm{~N}_{4} \mathrm{O}_{2}\right)$. Other fragments are summarised in Table. 5 and Scheme 2.

\section{Antimicrobial activity}

The response of the bacteria had been studied. We noticed the great biological influence of the Schiff base ligand and its complexes had been studied at previous concentration with pathogenic bacteria (Staphylococcus aureus), which is Gram Positive. While for the germ (Escherichia coli), which is a Gram negative bacteria, showed less response to ligand and its complexes studied from the other type of bacteria, characterized it's resistance to many chemical compounds and antibiotics ${ }^{35}$. The reason for this resistance is the colon bacteria that are found in a single bacilli containing thick casing surrounds of its cell. This casing contains a high proportion of lipid works to resist these materials from entering the cell, while the Staphylococcus aureus bacteria do not have this property, so it will be less resistant in the arrival of the chemical and antibiotic substances to internal of the bacterial cell19,36. Generally, the complexes showed biological effect more than the ligand(LI), although the ligand contains nitrogen and oxygen atoms biological retardant ${ }^{37}$.

The positive charge ion in the chelated complex is somewhat shared with the donor atoms orbital in the ligand and there is n-electron delocalization as compared with the entire chelate ring, which leads to reduction in the polarization of the metal ion to a bigger level. This in turn amplifies the lipophilic character of the metal chelate and helps its access throughout the lipid layers of the membrane the microorganisms ${ }^{38}$. The corresponding results are depicted in Tables 6 and Figure. 4.

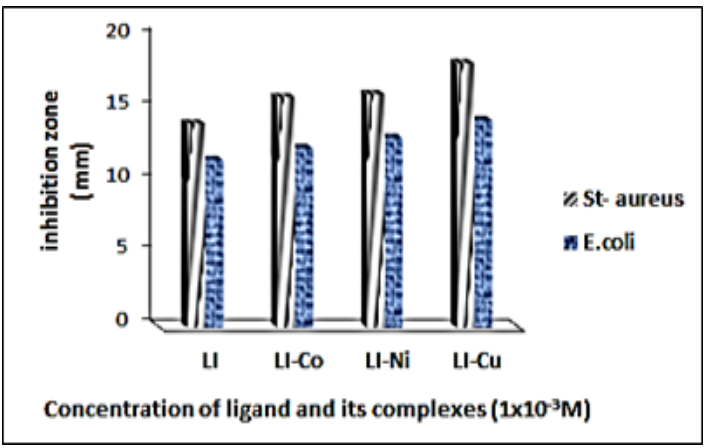

Fig. 4. The organic effects of Schiff base ligand (LI) and its complexes

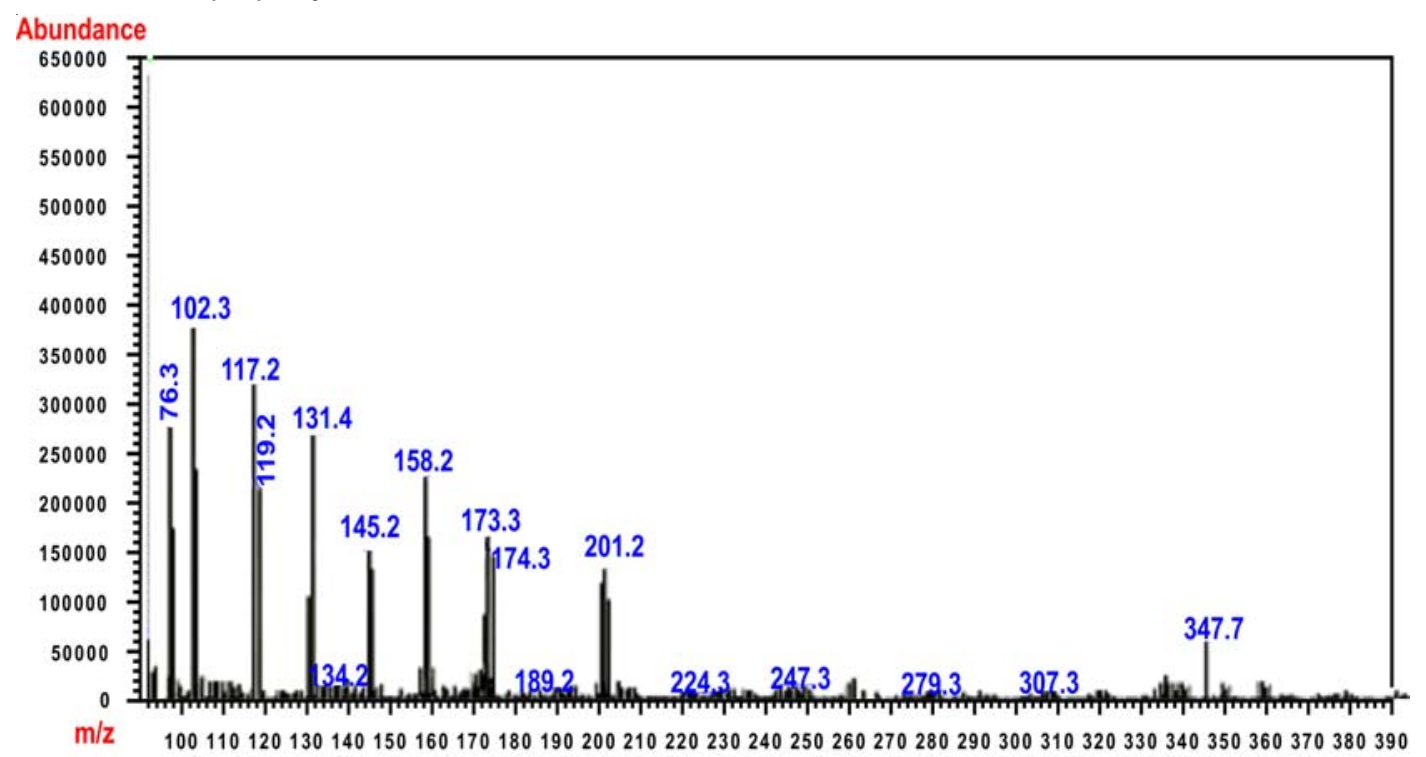

Fig. 3. Mass spectrum of the Schiff base ligand (LI) 
Table. 5: Mass spectral data of the Schiff base ligand (LI)

\begin{tabular}{lcc}
\hline Fragments & $\begin{array}{c}\text { Formula } \\
\text { weightg.mol-1 }\end{array}$ & $\begin{array}{c}\text { Relative } \\
\text { abundance } \%\end{array}$ \\
\hline $\mathrm{C}_{20} \mathrm{H}_{18} \mathrm{~N}_{4} \mathrm{O}_{2}$ & 346 & 12.22 \\
$\mathrm{C}_{12} \mathrm{H}_{13} \mathrm{~N}_{2} \mathrm{O}$ & 201 & 23.33 \\
$\mathrm{C}_{10} \mathrm{H}_{9} \mathrm{~N}_{2} \mathrm{O}$ & 173 & 27.78 \\
$\mathrm{C}_{9} \mathrm{H}_{6} \mathrm{~N}_{2} \mathrm{O}$ & 158 & 38.8 \\
$\mathrm{C}_{8} \mathrm{H}_{5} \mathrm{~N}_{2} \mathrm{O}$ & 145 & 27.8 \\
$\mathrm{C}_{8} \mathrm{H}_{5} \mathrm{NO}$ & 131 & 45.55 \\
$\mathrm{C}_{7} \mathrm{H}_{5} \mathrm{~N}_{2}$ & 117 & 54.4 \\
$\mathrm{C}_{7} \mathrm{H}_{4} \mathrm{~N}$ & 102 & 100 \\
$\mathrm{C}_{6} \mathrm{H}_{4}$ & 76 & 48.8 \\
\hline
\end{tabular}

Table. 6: The data of antibacterial activity (zone of inhibition) ( $\mathrm{mm}$ ) of Schiff base ligand (LI) and its complexes

\begin{tabular}{lcc}
$\begin{array}{lcc}\text { Compound } \\
\text { Bacteria }\end{array}$ & $\begin{array}{c}\text { Gram(+) } \\
\text { St- aureus }\end{array}$ & $\begin{array}{c}\text { Gram(-) } \\
\text { E.coli }\end{array}$ \\
\hline Control (S) DMSO & 6 & 6 \\
LI & 14 & 11.5 \\
LI-Co & 15.8 & 12.3 \\
LI-Ni & 16.2 & 13 \\
LI-Cu & 19.4 & 14.7 \\
\hline
\end{tabular}
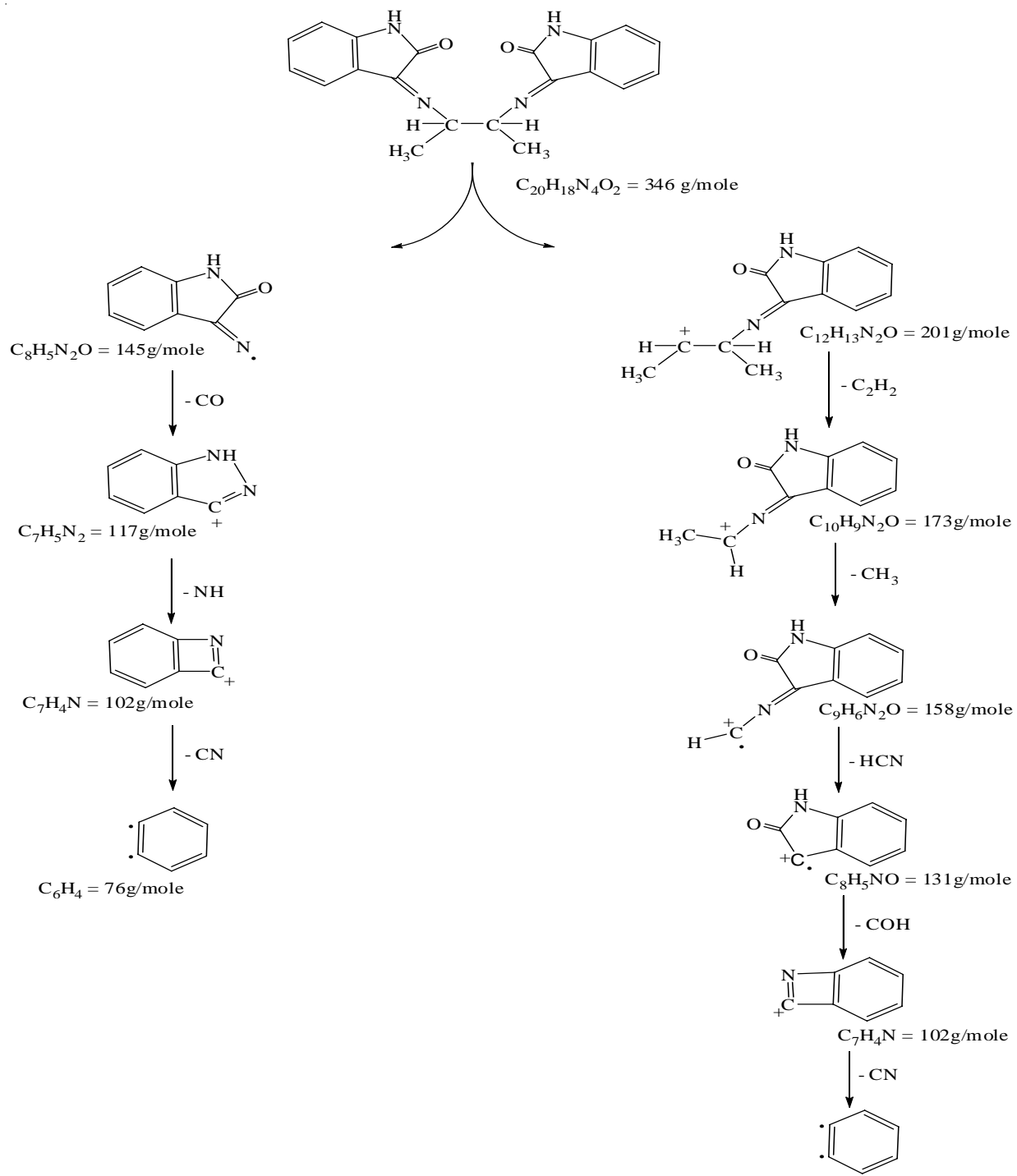

Scheme 2. The fragmentation of the Schiff base ligand (LI) 


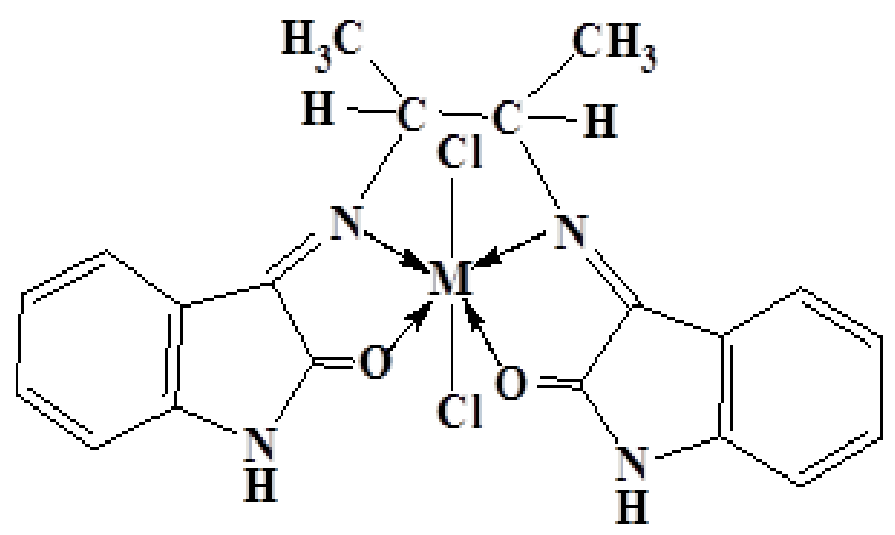

Fig. 5. The anticipated molecular structure of complexes, $\mathrm{M}(\mathrm{II})=\mathrm{Co}, \mathrm{Ni}$ and $\mathrm{Cu}$

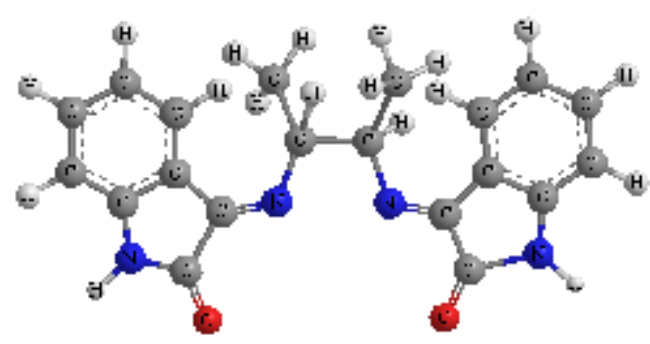

(a)

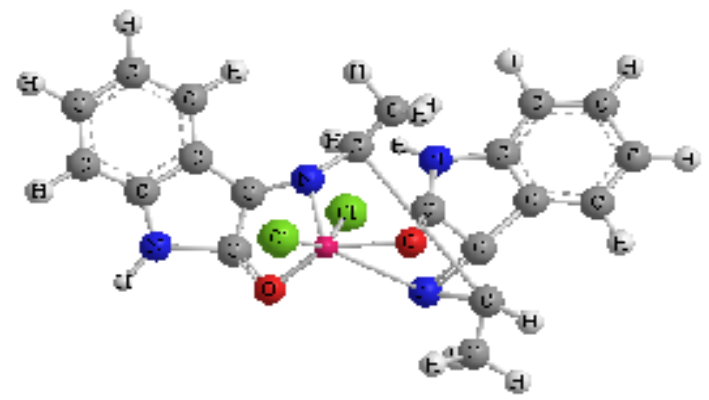

(b)

Fig. 6. The anticipated molecular 3D structure of (a) Schiff base ligand and (b) complexes, $\mathrm{M}(\mathrm{II})=\mathrm{Co}, \mathrm{Ni}$ and $\mathrm{Cu}$

\section{CONCLUSION}

The Schiff base ligand, LI, coordinates with $\mathrm{Co}(\mathrm{II}), \mathrm{Ni}(\mathrm{II})$ and $\mathrm{Cu}(\mathrm{II})$ ions through the tetradentate carbonyl and amino groups resulting in six-coordinated metal ions. These activities are with $M: L$ mole ratio of $1: 1$. The entire complexes are octahedral geometries as depicted in Fig. 5 and Fig. 6 in 3D structures. The biological activity results showed that all the compounds have variety of antibacterial activities.

\section{ACKNOWLEDGMENT}

I would like to state my sincere gratitude to the staff members of the Department of the Chemistry at the Faculty of Science. My gratitude and thanks to Dr. Ebtihal Kadhum Kareem for her support during the working period research. Sincere thanks and deep respect go to all my family and my wife for their encouragement.

\section{REFERENCES}

1. Pandeya, S.; Sriram, D. Act. Pharm. Ture., 1998, 1, 33-38.

2. Joaquim, F. M.; da Silva, Simon J. G.; 1999, J. Braz. Chem. Soc., 2001, 12, 273-324.

3. Ramachandram, S.; Maheshwari, V.;Int.J.Pharm.Bio Sci., 2011, 2, 251-260.

4. Bhrigu, B.; Pathak, D.; Siddiqui, N.; Alam,
M.S.; and Ashen, W. J. of Pharma.Scie. and Drug Res., 2010, 2, 229-235.

5. Lian-Shun, F.; Ming-Liang, L.; Shu, Z.; Yun, C.; Wang, B.; Yi-Bin, Z.; Kai, L.; Yan, G.; HuiYuan, G.; Chun-Ling, X. Eur. J. Med. Chem., 2011, 46, 341-348.

6. Praveen, C.; Ayyanar, A.; Perumal, P.T.. 
Bioorg. Med. Chem. Lett., 2011, 21, 4072-4077.

7. Ajaykumar, D. K.; Sangamesh, A. P.; Prema S. B. Int. J. Electrochem. Sci. 2009, 4, 717-729.

8. Singh, K.; Barwa, M.; Tyagi, P.; Eur J Med Chem., 2006, 41, 147-53.

9. Panneerselvam , P.; Nair, R..; Vijayalakshmi, G.; Subramanian, E.; Sridhar, S. K. Eur J Med Chem., 2005, 40, 225-9

10. Dharam, P.; Vandna, M.; Ramesh, K.; Krishan, K.. J. Serb. Chem. Soc., 2010, 75 , 763-772.

11. Muhammad, I.; Liviu, M.; Shoomaila, L.; Zaid, M.; Imtiaz, N.; Sana, S. Z.; Surrya, F. J. Serb. Chem. Soc., 2010, 75, 1075-1084.

12. Karia, F. D.; Parsania, P.H. Asian J. Chem., 1999, 11, 991-995.

13. Tarafder, M. T.; Kasbollah, A.; Saravan, N.; Crouse, K. A.; Ali, A. M.; Tin, O.K. J. Biochem. Mol. Biol. Biophs., 2002, 6, 85-91.

14. Kahveci, B.; Bekircan, O.; Karaoglu, S. A. J. Chem., 2005, 44, 2614-2617.

15. Bekircan, O.; Kahveci, B.; Kucuk, M. Tur. J. Chem., 2006, 30, 29-40.

16. Singh, W. M.; Dash, B. C. Pesticides., 1988, 22, 33-37.

17. Abdul-Ghani, A. J.; Asmaa, M. N.;. Bioinorg. Chem. and Appl. 2009, 2009, 1-12.

18. Zafar, H. A.; Khan, A. U.; Khan, T. A. J. Mol. Struct., 2015, 1097, 129-135.

19. Archer, R. D.; Wang, B. Inorg. Chem., 1990, 29, 39-43.

20. Kirby, W. A.; Bauer, A.W.; Sherris, J.; Turk, M. American. J. Clin.Pathol., 1966, 45, 493-496.

21. Gholamhassan, I.; Alireza, B.; Taarof, F.; Zahra, S. J. Green Chem. Lett. and Rev., 2017, 10, 1-9.

22. Ransheng, D.; Pegah, R. B.; Christian, W.J. Org. Chem, Amerc. Chem. Soci. 2017, 82, 1273-1278.

23. Timothy, R. H.; Noah, M. B.; Stephen, F. M.. J.Org. Lett., Americ. Chem. Soci., 2017,19,
2254-2257.

24. Sanapalli, S. R.;Ramjee, P.;Dong-Min, K.;MiSook W.;Yoon-Bo S. J. Chem. Pharm. Bull ., 2013, 61, 1105-1113.

25. Ayman, E. F.;Muhammad, F.;Sherine, N. K.;Nael , A.;Mohammad, A.; Wadaan, H. A. J. Molecules. 2015, 20, 14638-14655.

26. Ghodsi, M.; Ziarani, R.; Moradi, N.; Lashgari, A.; Badiei, A. S. J. Quimica Nova. 2015, 38, 1167-1171.

27. Gavrilo M. Sekularac J. B., Nikolic, P. P., Branko B., BobanD. and Sasaz. D.. J. Serb. Chem. Soc., 2014, 79 (11), 1347-1354.

28. Anita, S.; Manish, S.). J. Appl.Chem., 2013, 3,62-66.

29. Ramadoss, G.; Andy, R.; Athappan, M. J. of Innovat. Rese. in Scie., 2013, 2, 5156-5166.

30. Kareem, E. K.; Waddai,, F. Y. KufaJ.for Chem., 2016, 2, 62-75.

31. Kumar, M .P.; Tejasw, S. I.; Rambabu, A.; Kalalband, V.K. Polyhedron., 2015, 102, 111-120.

32. Waddai, F. Y.; Musa, F. H.; Fidhel, H. A. Kufa J. for Chem., 2016, 10, 38-55.

33. Waddai, F. Y., Musa, F. H.; Fidhel, H. A. Europ.Chem. Bull., 2015, 4, 74-79.

34. Chapman, J. R.. Pratical Organic Mass Spectrometry. 2nd. Ed, John Wiley., 1995, 110-111.

35. Ali, F. H.; Mussa, T. A.; Mithal, A. T. J. Chem. Pharm. Res., 2014, 6, 44-51.

36. Rehab A. M.; Eiman, S. K. Asian J. of Biochem. and Pharma. Resea., 2013, 3, 1-2.

37. Ranajit, K. R. Electronic spectra of transition metal complexes. 1st Ed., NCBA Publish. India -New Delhi., 2012, 10, 514.

38. Alaa, F. M.; Sami, W. R. J. Sci.Al-Mustansiriyah, Baghdad-Iraq., 2014, 25, 41-50. 